\title{
The Role of Legislative Aides in Attaining the Sustainable Development Goals (SDGs) in Nigeria
}

\author{
Livinus A. NANDI \& OLUSEGUN B. Maiye \\ National Institute for Legislative and Democratic Studies, National Assembly, Abuja, Nigeria
}

\section{INTRODUCTION}

The need to make global development holistic has been in the forefront of the agenda of the United Nations (UN). No doubt that the international organization has been developing frameworks to help reduce the gaps in development between the first and third world countries. One of these frameworks in the Millennium Development Goals (MDGs) which was later replaced in 2015 by Sustainable Development Goals (SDGs). One of the major challenges faced by the former MDGs was its inability to get local legislation by member states of the United Nations Development Programme (UNDP).

The SDGs, which came into effect in January 2016, are a universal set of economic, social and environmental goals and targets that member states of the UN are expected to achieve by 2030 . The SDGs build and expand on the eight MDGs by focusing on critical dimensions of sustainable development in both emerging and advanced countries, ranging from human rights obligations, good governance, social justice, equity within countries, environmental sustainability, vulnerability to the exclusion of marginal populations and the poorest of the poor (Meyer-Ohlendorf, Gorlach, and McFarland, 2013).

Like the MDGs, the SDGs will not be legally binding; they represent a political commitment to development by all UN member states (Meyer-Ohlendorf et al., 2013). Ultimately, these universal goals are meant to create a standard that ensures the balancing of economic development and global environmental goals with poverty reduction objectives (Sachs, 2012).

Until now, the debates surrounding SDGs have mainly concerned the setting of goals and indicators. Less attention has been paid to discussing the roles and responsibilities that different stakeholders should take in achieving these goals in particular, how to best implement this universal framework at the local level. Given the scope and ambition of the SDGs, it is clear that governments alone cannot achieve the agenda. They must also ensure the participation of all sectors of society, including legislative aides, the private sector and the general public at the local level. Localisation has to do with the process of defining, implementing and monitoring strategies at the local level for achieving global, national and sub-national sustainable development targets. It involves various concrete mechanisms, tools, innovations, platforms and processes to effectively translate the development agenda into results at the local level" (GTF et al., 2014: 5).
In other words, localisation is the local implementation of the new set of goals and the monitoring of progress at the subnational level (Lucci, 2015). Localisation should be conceptualised in a holistic manner and include civil society, local governments at the frontline of development, traditional leaders, religious organisations, the private sector, citizens and other parties (GTF et al., 2014).

The inclusion of legislative aides in these processes is imperative, for these actors play crucial roles in society as agents of parliamentary efficiency. In the Nigerian context, the inclusion of legislative aides is important because governance is based on legality of the constitutions. Therefore, it is essential to unravel the potential roles of legislative aides in the effective implementation of the SDGs as well as to enhance their engagement, impact and effectiveness in global development processes.

\section{Legislature as a Concept}

Legislature is referred as Parliament in Britain, National Assembly in Nigeria, Congress in the United States (Abonyi, 2006). The legislature occupies a key position in the democratic process of government, with the purpose of articulating the collective will of the people through representative government (Okoosi-Simbine, 2010). Awotokun (1998) states that legislature is an arm of government made up of elected representatives or constituted assembly of people whose duty is to make laws, control the activities of the executive and safeguard people's interest.

Anyaegbunam (2000) define legislature as the role of making, revising, amending and repealing laws for the well-being of its citizenry it represents. Lafenwa (2009) conceives the legislature as people chosen by election to represent the constituent units and control government. Okoosi-Simbine (2010) asserts that legislature is law-making, and policy influencing body in the democratic political system. The law makers can be described in the site of sovereignty, the expression on the will of the people. This is derived from the people and should be exercised according to the will of the people they represent.

Bogdanor (1991) affirms that legislature is derived from a claim that its members are representatives of the political community, and decisions are collectively made according to complex procedures. The state of the legislature has been identified as the strongest predictors on the survival of every democratic development (Okoosi-Simbine, 2010). The 
centrality of the legislature is captured by Awotokun (1998) when he asserts that legislature is the pivot of modern democratic systems. Edosa \& Azelama (1995) states that legislatures vary in design, structure, organisation, operational procedures, and selection process as well as sizes, tenure of office and nature of meetings.

In a bicameral type of arrangement two legislative chambers exist in a country; one chamber seems to dominate the other. Nwabueze and Muller (1985) noted that when they viewed that there exist some forms of dominance of one chamber to the other in some legislation, term of office, size of the constituencies represented. However, they intricate rules adopted usually harmonize the legislative function of the two chambers (upper and lower chamber). Edosa and Azelama (1995) assert that bicameral legislative is common in federal states that stem from the imperative of one house to protect the interests of minority groups in such states. Nigeria operates in a federally bicameral arrangement on the dictates of 1954 Lyttleton Constitution. The House of Senate (Upper House) and House of Representatives (Lower House) jointly called National Assembly of Nigeria. The two chambers act as a check on other arms of government; such checks are minimal because the major policy demand debate is on party affiliations rather than national interest (Edosa \& Azelama, 1995). This arrangement enhance passage of law and gives opportunity for division of labour between the two houses (Okoosi-Simbine, 2010).

In addition, bicameral legislature provides an opportunity for wider representation of various interests groups in a country from one democracy to the other. Nwabuzor and Muller (1985) notes that such factors like presiding officer, order of business, legislative process, legislative committee, intra-party discipline manner of debate consideration account differently among countries. Nwabuzor and Muller (1985) assert that countries that operate short-term tenure for legislature do so because the representatives reflect on the betterment of public preference in respect of government policy. The long-term tenure ensures the stability of national interests which has no changing public opinion. From the foregoing, the legislature can be defined as the body that is recognized by the constitution to make laws and ensure the will of the people is always uphold in the law.

\section{Legislative Oversight}

Legislative oversight refers to the legislature's review and evaluation of selected activities of the executive branch of government. The legislative branch conducts oversight activities because it has not only the power to enacts new programs for the state, but also has a duty to ensure that existing programs are implemented and administered efficiently, effectively, and in a manner consistent with legislative intent. While oversight is one of the major focuses of legislative committees, it is an integral part of the legislative process that is often difficult to separate from the law-making process. Oversight is the focus of some selected committees and special oversight committees and can also be part of the hearings and work of standing committees (StairHall, 2011).

According to Stair-Hall (2011), the budget process includes many oversight activities, because during the annual appropriation process, the National Assembly must relate the overall value of a program to other programs competing for funding from limited state resources. To some extent, legislature determine relative funding levels for programs on the basis of information they receive by questioning executive branch's administrators during budget hearings. Oversight as an outgrowth of this principle serves a number of overlapping objectives and purposes which include;

a. Improvement in the efficiency, economy, and effectiveness of governmental operations;

b. Evaluation of programs and performance;

c. Detection and prevention of poor administration, waste, abuse, arbitrary and capricious behaviour, or illegal and unconstitutional conduct;

d. Protection of civil liberties and constitutional rights;

e. Informing the general public and ensuring that executive policies reflect public interest;

f. Gathering information to develop new legislative proposals or to amend existing statutes;

g. Ensuring administrative compliance with legislative intent; and

h. Prevention of executive encroachment on legislative authority and prerogatives.

In a bicameral type of arrangement two legislative chambers exist in a country; one chamber seems to dominate the other. Nwabueze and Mueller (1985) noted that there exist some forms of dominance of one chamber over the other in some legislature; term of office, size of the constituencies, represented. However, the intricate rules adopted usually harmonize the legislative functions of the two chambers (upper and lower ones). Edosa and Azelama (1995) assert that bicameral legislature is common in federal states that stem from the imperative of one house having to protect the interests of minority groups in such states.

Nigeria operates a federally bicameral legislative arrangement beginning from the 1954 Lyttleton Constitution. The House of Senate (Upper House) and House of Representatives (Lower House) jointly called the Nigerian Parliament. The two chambers act as a check on each other but; such checks are toward a stronger position. This arrangement enhances passage of law and gives opportunity for division of labour between the two houses (Okoosi-Simbine, 2010). In addition, bicameral legislature provides an opportunity for wider representation of various interest groups in a country. Nwabuzor and Muller (1985) notes that such factors like presiding officer, order of business, legislative process, legislative committee, intra-party discipline manner of debate consideration account differently among countries. Nwabuzor and Muller (1985) assert that 
countries that operate short-term tenure for legislature do so because the representatives reflect on the betterment of public preference in respect of government policy. The long-term tenure ensures the stability of national interests which has no changing public opinion.

Writing on the role of parliamentary committees, Stapenhurst (2012) submitted that legislative committees are the engine rooms of the Legislature, and where the committee system is underdeveloped, the budgetary role of the legislature tends to be weak. Pelizzo and Stapenhurst, (2008) asserted that specialized committees have emerged as fundamental tools for oversight in general and for the budget process and spending of public monies in particular. In many parliaments, the Public Accounts Committee (PAC) serves as the audit committee of parliament, making it a core institution of public financial accountability.

Anderson (2008) noted that effective oversight committees are most often those with supportive staff, useful partners, and allies from the bureaucracy and civil society. Legislatures and their committees are often assisted in their oversight function by extra parliamentary accountability institutions, such as supreme audit institutions and ombudsmen. Parliamentary budget office may also provide independent expertise and support to parliament. The author stressed the potential value of such independent analytical budget units in putting the legislature on a more equal footing with the executive and in increasing the overall transparency, credibility, and accountability of the budget process and such units must be nonpartisan, independent, and objective to successfully fulfill their core functions (Anderson, 2008).

\section{THEORETICAL FRAMEWORK}

Structural functionalism as it is often called, intends to explain the basis for the maintenance of order and stability in society and the relevant arrangements within the society, which maintain the said order and stability. In our formulation of a structural functional framework, social processes and social mechanisms are intervening variables. A complete description of a social system would include, therefore, a treatment of the social structures, and various functions of these structures; and of the social processes and mechanisms that must be in operation if structures are to satisfy certain functions (Holt, 1967).

According to Enemuo (1999) Gabriel Almond, one of the chief proponents of the approach (structural functionalism) in political science avers that every political system performs certain functions. Taking Easton's systems analysis as a starting point, Almond looks for the functions which could be included among the input and output functions of all political systems. On the input side are the functions of interest articulation and interest aggregation. Second, on the output side are the functions of rulemaking, rule application and rule adjudication. The function of political communication is undertaken to inform all within the political system and outside of the diverse activities. Additionally, every system performs systems maintenance and adaptation functions through political socialization and recruitment of people.

According to Almond and Powell (1969:16) the functioning of any political system may also be viewed in terms of its capabilities, which is the way it performs as a unit in its environment. The concepts of regulative, extractive, distributive and responsive capability are employed as criteria to assess how a system is performing within its environment, how it is shaping its environment, and how it is being shaped by the environment as well. No doubt, structural functionalism revolves around two focal conceptionsfunctions and structures.

Nwagwu (2010) stresses that while functions deal with the consequence that is, involving objectives as well as processes of patterns of actions (like capacity to make and implement sound anti-corruption laws and appropriate punishment for violations irrespective of the culprits), and structure on the other hand refers to the arrangements within the system, which performs the functions. The legislature in Nigeria is a structure that performs the major function of law making. This is done by the legislators working with their aides for efficiency and effectiveness. The aides have invaluable roles to play in the actualization of all the items in the SDGs.

\section{The Sustainable Development Goals (SDGs)}

The SDGs was drafted from the MDGs of the UN after the assessment of the latter. The following goals are set as SDGs by the members of the UN in 2016 and the target they choose to achieve before the 2030

\section{Goal 1: End Poverty in All Its Forms Everywhere}

The targets of this goal is to reduce at least by half the proportion of men, women and children of all ages living in poverty (less than $\$ 1.25$ a day); implement nationally appropriate social protection systems and measures for all, including floors, and by 2030 achieve substantial coverage of the poor and the vulnerable. Ensure access of all, particularly the poor and the vulnerable, to basic services, ownership, and control over land and other forms of property, inheritance, natural resources, appropriate new technology, and financial services including microfinance and build the resilience of the poor and those in vulnerable situations.

Goal 2: End Hunger, Achieve Food Security and Adequate Nutrition for All, and Promote Sustainable Agriculture

This is to ensure access by all people, in particular the poor and people in vulnerable situations including infants, to safe, nutritious and sufficient food all year round; achieving by 2025 the internationally agreed targets on stunting and wasting in children under five years of age, and address the nutritional needs of adolescent girls, pregnant and lactating women, and older persons. Double the agricultural productivity and the incomes of small-scale food producers, particularly women, indigenous peoples, family farmers, pastoralists and fishers, including through secure and equal 
access to land, other productive resources and inputs, knowledge, financial services, markets, and opportunities for value addition and non-farm employment; ensure sustainable food production systems and implement resilient agricultural practices

Member states are to increase investment, including through enhanced international cooperation, in rural infrastructure, agricultural research and extension services, technology development, and plant and livestock gene banks. Also, to correct and prevent trade restrictions and distortions in world agricultural markets including by the parallel elimination of all forms of agricultural export subsidies and all export measures with equivalent effect

\section{Goal 3: Attain Healthy Life for All at All Ages}

The targets of this goal are to reduce the global maternal mortality ratio to less than 70 per 100,000 live births and end preventable deaths of newborns and under-five children; end epidemics of AIDS, tuberculosis, malaria, and neglected tropical diseases and combat hepatitis, water-borne diseases, and other communicable diseases; reduce by one-third premature mortality NCDs. Ensure universal access to sexual and reproductive health care services, and the integration of reproductive health into national strategies and programmes; halve global deaths and injuries from road traffic accidents; achieve universal health coverage (UHC); substantially reduce the number of deaths and illnesses from hazardous chemicals and air, water, and soil pollution and contamination. States are to strengthen implementation of the Framework Convention on Tobacco Control in all countries as appropriate support research and development of vaccines and medicines for the communicable and non-communicable diseases that primarily affect developing countries, provide access to affordable essential medicines and vaccines, in accordance with the Doha Declaration.

\section{Goal 4: Provide Equitable and Inclusive Quality Education and Life-Long Learning Opportunities for All}

To reduce the global maternal mortality ratio to less than 70 per 100,000 live births and end preventable deaths of newborns and under-five children; end epidemics of AIDS, tuberculosis, malaria, and neglected tropical diseases and combat hepatitis, water-borne diseases, and other communicable diseases; reduce by one-third pre-mature mortality non-communicable diseases.

Ensure universal access to sexual and reproductive health care services, and the integration of reproductive health into national strategies and programmes; halve global deaths and injuries from road traffic accidents; achieve universal health coverage (UHC); substantially reduce the number of deaths and illnesses from hazardous chemicals and air, water, and soil pollution and contamination.

To achieve this set goal, states are to strengthen implementation of the Framework Convention on Tobacco Control in all countries as appropriate support research and development of vaccines and medicines for the communicable and non-communicable diseases that primarily affect developing countries, provide access to affordable essential medicines and vaccines, in accordance with the Doha Declaration.

\section{Goal 5; Attain Gender Equality, Empower Women and Girls Everywhere}

This goal is to end all forms of discrimination against all women and girls everywhere, eliminate all forms of violence against all women and girls in public and private spheres, including trafficking and sexual and other types of exploitation eliminate all harmful practices, such as child, early and forced marriage and Female Genital Mutilation. It recognize and value unpaid care and domestic work through the provision of public services, infrastructure and social protection policies ensure women's full and effective participation and equal opportunities for leadership at all levels of decision-making in political, economic, and public life

Members of the UN are to carry out reforms to give women equal rights to economic resources, as well as access to ownership and control over land and other forms of property, financial services, inheritance, and natural resources in accordance with national laws. Enhance the use of enabling technologies, in particular ICT, to promote women's empowerment. Adopt and strengthen sound policies and enforceable legislation for the promotion of gender equality and empowerment. These require relevant legislations by the Nigerian National Assembly.

\section{Goal 6: Secure Water and Sanitation for All for a Sustainable} World

Members of the UN are to achieve universal and equitable access to safe and affordable drinking water for all; access to adequate and equitable sanitation and hygiene for all; end open defecation, paying special attention to the needs of women and girls and those in vulnerable situations; improve water quality by reducing pollution, eliminating dumping and minimizing release of hazardous chemicals and materials, halving the proportion of untreated wastewater, and increasing recycling and safe reuse by $\mathrm{x} \%$ globally

Increase water-use efficiency across all sectors and ensure sustainable withdrawals and supply of freshwater to address water scarcity, and substantially reduce the number of people suffering from water scarcity; implement integrated water resource management at all levels, including through transboundary cooperation as appropriate. By 2020 protect and restore water-related ecosystems, including mountains, forests, wetlands, rivers, aquifers and lakes; expand international cooperation and capacity-building support to developing countries in water and sanitation related activities and programmes, including water harvesting, desalination, water efficiency, wastewater treatment, recycling and re-use technologies 
Goal 7: Ensure Access to Affordable, Sustainable, and Reliable Modern Energy Services for All

2030 ensure universal access to affordable, reliable, and modern energy services; increase substantially the share of renewable energy in the global energy mix by 2030; double the global rate of improvement in energy efficiency by 2030 ; enhance international cooperation to facilitate access to clean energy research and technologies, including renewable energy, energy efficiency, and advanced and cleaner fossil fuel technologies, and promote investment in energy infrastructure and clean energy technologies expand infrastructure and upgrade technology for supplying modern and sustainable energy services for all in developing countries, particularly LDCs and SIDS

\section{Goal 8: Promote Strong, Inclusive and Sustainable Economic Growth and Decent Work for All}

To sustain per capita economic growth in accordance with national circumstances, and in particular at least $7 \%$ per annum GDP growth in the least-developed countries; achieve higher levels of productivity of economies through diversification, technological upgrading and innovation, including through a focus on high value added and laborintensive sectors; promote development-oriented policies that support productive activities, decent job creation, entrepreneurship, creativity and innovation, and encourage formalization and growth of micro-, small- and medium-sized enterprises including through access to financial services

Improve global resource efficiency in consumption and production, and endeavor to decouple economic growth from environmental degradation in accordance with the 10-year framework of programmes on sustainable consumption and production with developed countries taking the lead

Prohibition and elimination of the worst forms of child labour, eradicate forced labour, and by 2025 end child labour in all its forms including recruitment and use of child soldiers. Protect labour rights and promote safe and secure working environments of all workers, including migrant workers, particularly women migrants, and those in precarious employment; devise and implement policies to promote sustainable tourism which creates jobs, promotes local culture and products strengthen the capacity of domestic financial institutions to encourage and to expand access to banking, insurance and financial services for all. Increase Aid for Trade support for developing countries, particularly LDCs, including through the Enhanced Integrated Framework for LDCs

\section{Goal 9: Promote Sustainable Industrialization}

Develop quality, reliable, sustainable and resilient infrastructure, including regional and trans-border infrastructure, to support economic development and human well-being, with a focus on affordable and equitable access for all; promote inclusive and sustainable industrialization,
By 2030 raise significantly industry's share of employment and GDP in line with national circumstances, and double its share in LDCs. Increase the access of small-scale industrial and other enterprises, particularly in developing countries, to financial services including affordable credit and their integration into value chains and markets. Upgrade infrastructure and retrofit industries to make them sustainable, with increased resource use efficiency and greater adoption of clean and environmentally sound technologies and industrial processes, all countries taking action in accordance with their respective capabilities enhance scientific research.

\section{Goal 10: Reduce Inequality Within and Among Countries}

Members are to empower and promote the social, economic and political inclusion of all irrespective of age, sex, disability, race, ethnicity, origin, religion or economic or other status; ensure equal opportunity and reduce inequalities of outcome, including through eliminating discriminatory laws, policies and practices and promoting appropriate legislation, policies and actions in this regard; adopt policies especially fiscal, wage, and social protection policies and progressively achieve greater equality; improve regulation and monitoring of global financial markets and institutions and strengthen implementation of such regulations;

Ensure enhanced representation and voice of developing countries in decision making in global international economic and financial institutions in order to deliver more effective, credible, accountable and legitimate institutions; facilitate orderly, safe, regular and responsible migration and mobility of people, including through implementation of planned and well-managed migration policies Goal 11: Build Inclusive, Safe and Sustainable Cities and
Human Settlements

States are to ensure access for all to adequate, safe and affordable housing and basic services, and upgrade slums, sustainable transport systems for all, improving road safety, notably by expanding public transport, with special attention to the needs of those in vulnerable situations, women, children, persons with disabilities and older persons, enhance inclusive and sustainable urbanization and capacities for participatory, integrated and sustainable human settlement planning and management in all countries. Strengthen efforts to protect and safeguard the world's cultural and natural heritage, significantly reduce the number of deaths and the number of affected people and decrease by $\mathrm{y} \%$ the economic losses relative to GDP caused by disasters, including waterrelated disasters, with the focus on protecting the poor and people in vulnerable situations

Goal 12: Promote Sustainable Consumption and Production Patterns

Implement the 10-Year Framework of Programmes on sustainable consumption and production (10YFP), all countries taking action, with developed countries taking the lead, taking into account the development and capabilities of 
developing countries. Achieve sustainable management and efficient use of natural resources. Halve per capita global food waste at the retail and consumer level, and reduce food losses along production and supply chains including post-harvest losses. By 2020 achieve environmentally sound management of chemicals and all wastes throughout their life cycle in accordance with agreed international frameworks and significantly reduce their release to air, water and soil to minimize their adverse impacts on human health and the environment. By 2030, substantially reduce waste generation through prevention, reduction, recycling, and reuse.

\section{Goal 13: Promote Actions at All Levels to Address Climate Change}

Strengthen resilience and adaptive capacity to climate related hazards and natural disasters in all countries; Integrate climate change measures into national policies, strategies, and planning; improve education, awareness raising and human and institutional capacity on climate change mitigation, adaptation, impact reduction, and early warning. Implement the commitment undertaken by developed country Parties to the UNFCCC to a goal of mobilizing jointly USD100 billion annually by 2020 from all sources to address the needs of developing countries in the context of meaningful mitigation actions and transparency on implementation and fully operationalize the Green Climate Fund through its capitalization as soon as possible. Promote mechanisms for raising capacities for effective climate change related planning and management, in LDCs, including focusing on women, youth, local and marginalized communities.

\section{Goal 14: Attain Conservation and Sustainable Use of Marine} Resources, Oceans and Seas

By 2025, prevent and significantly reduce marine pollution of all kinds, particularly from land-based activities, including marine debris and nutrient pollution. By 2020, sustainably manage and protect marine and coastal ecosystems to avoid significant adverse impacts, including by strengthening their resilience, and take action for their restoration, to achieve healthy and productive oceans; minimize and address the impacts of ocean acidification, including through enhanced scientific cooperation at all levels. By 2020, effectively regulate harvesting, and end overfishing, illegal, unreported and unregulated (IUU) fishing and destructive fishing practices and implement science-based management plans, to restore fish stocks in the shortest time feasible at least to levels that can produce maximum sustainable yield as determined by their biological characteristics. By 2020, conserve at least 10 per cent of coastal and marine areas, consistent with national and international law and based on best available scientific information

Goal 15: Protect and Restore Terrestrial Ecosystems and Halt All Biodiversity Loss

By 2020 ensure conservation, restoration and sustainable use of terrestrial and inland freshwater ecosystems and their services, in particular forests, wetlands, mountains and dry lands, in line with obligations under international agreements. Promote the implementation of sustainable management of all types of forests, halt deforestation, restore degraded forests, and increase afforestation and reforestation by $\mathrm{x} \%$ globally; combat desertification, and restore degraded land and soil, including land affected by desertification, drought and floods, and strive to achieve a land-degradation neutral world. By 2030 ensure the conservation of mountain ecosystems, including their biodiversity, to enhance their capacity to provide benefits which are essential for sustainable development; take urgent and significant action to reduce degradation of natural habitat, halt the loss of biodiversity, and by 2020 protect and prevent the extinction of threatened species.

Goal 16: Achieve Peaceful and Inclusive Societies, Rule of Law, Effective and Capable Institutions

Significantly reduce all forms of violence and related death rates everywhere; end abuse, exploitation, trafficking and all forms of violence and torture against children. Promote the rule of law at the national and international levels, and ensure equal access to justice for all. Significantly reduce illicit financial and arms flows, strengthen recovery and return of stolen assets, and combat all forms of organized crime substantially reduce corruption and bribery in all its forms; develop effective, accountable and transparent institutions at all levels. Broaden and strengthen the participation of developing countries in the institutions of global governance strengthen relevant national institutions, including through international cooperation, for building capacities at all levels, in particular in developing countries, for preventing violence and combating terrorism and crime. Promote and enforce nondiscriminatory laws and policies for sustainable development and provide legal identity for all including birth registrations

Goal 17: Strengthen and Enhance the Means of Implementation and Global Partnership for Sustainable Development

Strengthen domestic resource mobilization, including through international support to developing countries to improve domestic capacity for tax and other revenue collection. Developed countries are to implement fully their ODA commitments, including providing $0.7 \%$ of GNI in ODA to developing countries of which $0.15-0.20 \%$ to least-developed countries. Also to mobilize additional financial resources for developing countries from multiple sources and assist developing countries in attaining long-term debt sustainability through coordinated policies aimed at fostering debt financing, debt relief and debt restructuring, as appropriate, and address the external debt of highly indebted poor countries (HIPC) to reduce debt distress by adopting and implementing investment promotion regimes for Less Developed Countries 


\section{Legislative Aides and the SDGs}

The Legislative Aides oversees the operation and administration of a legislator. Legislative aides are nonpartisan and do not attempt to influence members of the legislature, other State employees, or members of the general public regarding policy matters or pending legislation. Given the nonpartisan nature of the position, all employees including the Legislative Assistant are prohibited from engaging in certain political activities. Legislative members of staff are expected to maintain high professional, ethical and confidentiality standards consistent with office policies when interacting with legislators, lobbyists, the media and the general public.

The Legislative aide carries out a variety of functions both independently and in a team relations with other personnel.

Legislative aides are powerful agents of change. It is by ratifying international agreements, translating the SDGs into enforceable national laws that respond to country-specific development priorities, monitoring their implementation and ensuring government is accountable to the people for national progress on the SDGs, that parliaments can drive that change. By regularly holding hearings and requesting plenary reports, the legislature can bring the SDGs to the attention of the public and the media, thereby encouraging accountability at all levels of government. In representing those who elected them, and offering a platform for communication, parliaments can ensure an ongoing dialogue with civil society over the SDGs. Parliaments can ensure the process of developing a national development vision is informed by an inclusive and participatory political dialogue. Through annual parliamentary reviews of proposed government expenditures, parliaments can ensure adequate financial resources are allocated to the achievement of the post- 2015 objectives and that sustainable development priorities are reflected in national and local budgets. Their engagement on and oversight of the implementation of national development plans that put the well-being of the people up front and centre can make parliaments the linchpin for success in driving development forward.

Leaving no one behind is an underlying principle of the SDGs. Its aim is to ensure that development throughout the world has positive impacts on the poorest and most marginalized members of society. A key criticism of the MDGs in this respect was that national or aggregated statistics do not reflect the geography of deprivation at the local level, and certain areas that are home to the poorest and most marginalized citizens in society have taken a step backwards (UN, 2008; Miyazawa, 2012). One of the aims of localization is to put the last first (Chambers, 1983) and to ensure that areas of relative deprivation are targeted when implementing the SDGs at the local level. To represent the interests of the poorest and most marginalized members of society at the local level, the the following recommendations are put forward by this paper:
1. Legislative aides should be proactive in gathering information and interacting with members of their communities by creating opportunities, spaces and platforms for engaging with these groups in order to promote genuine dialogues, build community awareness and develop strong relationships. The interactions should work both ways: legislative aides should provide feedback to these groups on steps they are taking to address concerns and progress made on the legislative works of the National Assembly on certain key areas of the SDGs.

2. Aides should translate the voices of the poorest and most vulnerable citizens into rational or strong arguments that are acknowledged and addressed by the legislators. The SDGs represent a globally legitimate frame of reference for legislative aides, which can introduce issues into law making process.

3. Legislative aides should identify integrated improvements or interventions that could make a significant difference for vulnerable people. Aides should also emphasize the value of locally tailored solutions in achieving local and global development goals.

4. Develop relationships or partnerships with the stakeholders, and in particular, identify the government departments, actors or institutions that need to respond in order to remedy problems. Moreover, they can ensure that action is taken by the responsible person or department, and if this is not the case, they should also follow up with the relevant government officials or departments.

5. Legislative aides should be allowed to play a critical role as transformers in society by being involved in training and advocacy processes, which build the capacities and knowledge of the general populace towards achieving the SDGs. This will ensure that people become the focus of the SDGs and that the most vulnerable in society are not left behind when these global development goals are better localized.

6. Appointment of aides by Nigerian legislators should be based on merit even in the face of political considerations. This will make them more useful outside political mobilizations.

\section{CONCLUSION}

No doubt that the legislative aides like the legislators are important actors in the attainment of the UN SDGs. The roles highlighted in this paper reflect the value that legislative aides bring to society and, in particular, how legislative aides can best contribute to achieving the SDGs at the local level. As legislative aides are recognised as having an increasingly important role in carrying out legislative functions, their roles in the attainment of SDGs can never be wished away. It is because the legislators cannot be islands of knowledge in the discharge of their oversights, representations, legislations and appropriations that the laws provide them with aides, these 
aides must assist efficiently even in the course of ensuring that Nigeria does not lag behind in the realization of the Sustainable Development Goals (SDGs).

\section{REFERENCES}

[1] Abonyi, N (2006) Intergovernmental Relations in Democratic Federations. Enugu: John Jacob's Classic Publishers Ltd.

[2] Adebo, A. (1988): "The Legislature: Overview and Performance". In Ayeni Victor and Soremekun K (eds.) Nigeria's Second Republic. Lagos: Daily Times Publications. 85-106.

[3] Almond, G. A. (1956). Comparative political systems. Journal of Polítics, 18,391409.

[4] Almond, G. A., \& Powell, G. 8., Jr. (1966). Comparative politics: A developmental qpproach, Boston Little, Brown.

[5] Anderson, J. (2001), "Political Parties' in Hawkes worth, M. and Kogan, M. (eds.) Encyclopedia of Government and Politics, Vol.1, London and New York: Routledge

[6] Anyaegbunam, E. O. (2000) Assembly Handbook: A Legislator's Companion. Lagos: FEF.

[7] Awotokun, K (1998) Governance and Legislative Control in Nigeria Lessons from the Second and Third Republics Bethesda: International Scholars Publications.

[8] Bogdanor, V. (1991). The Blackwell Encyclopedia of Political Science. Oxford: Blackwell Publishers.

[9] Constitution of Federal Republic of Nigeria (1999) as Amended

[10] Davies, A. E. (2004) "The Role of the Legislature in Fostering an Efficient System of Public Finance" in Fageigbesi (eds.) Fiscal Federalism. CEMA/ACBE.

[11] Edosa, E. and Azelama, J. (1995): "Institutions of Government." In Ikelegbe, A.

[12] Enemuo, F. (1999), Gender and Women Empowerment, in Anifowose, R. and Enemuo, F. (eds.), Elements of Politics, Lagos: Malthouse Press Ltd

[13] Gandure, S. and Kumwenda, H. (2013). "Draft Report on Sustainable Development Goals for the Southern Africa Subregion." Africa Regional Consultative Meeting on the Sustainable Development Goals, 31 October-2 November 2013, Addis Ababa, Ethiopia.

[14] Ghaus-Pasha, A. (2004). "Role of Civil Society Organisation in Governance." Paper presented at 6th Global Forum on Reinventing Government towards Participatory and Transparent Governance, 24-27 May 2005, Seoul, South Korea.

[15] Global Task Force of Local and Regional Governments for Post2015 Development Agenda Towards Habitat III, United Nations Development Program and United Nations Habitat (GTF et al., 2015). "Key Messages and Process on Localizing the Post-2015 agenda."

http://www2.dse.unibo.it/ardeni/Key\%20Messages\%20and\%20Pr ocess\%20on\%20 Localizing\%20the\%20Post-2015\%20agenda.pdf. Accessed 6 October 2015.

[16] Holt, R (1967). The Methodology of Comparative Research, New York: The Free Press.

[17] https://sustainabledevelopment.un.org/content/.../1023nigerianatio nalreport

[18] Kumar S, Kumar N, Vivekadhish S. Millennium Development Goals (MDGs) to Sustainable Development Goals (SDGs): Addressing Unfinished Agenda and Strengthening Sustainable Development and Partnership. Indian Journal of Community Medicine: Official Publication of Indian Association of Preventive \& Social Medicine. 2016; 41(1):1-4.doi:10. 4103/ 09700218.170955.

[19] Lafenwa, R. (2009) The Nigerian Legislative Process; Bills, Budgetary Control and Committee System. Abuja: Law-Link Consult.

[20] Lucci, P. (2015). "'Localising' the Post-2015 agenda: What does it mean in practice?" Overseas Development Institute Report. http://www.odi.org/sites/odi.org.uk/files/odi-assets/publicationsopinion-files/9395.pdf. Accessed 6 October 2015.
[21] Meyer-Ohlendorf, N., Gorlach, B. and McFarland, K. (2013). "Towards Sustainable Development Goals: Working Paper," Umweltbundesamt, Berlin, Germany.

[22] Mezey, M. L. (1979). Comparative Legislatures. Durham, NC: Duke University Press.

[23] Nigerian National Bureau of Statistics (2015)

[24] Nwabuzor, D and Muller, E. (1985), "Political Leadership in a Plural Society,” in J. A. A. Ayoade et'al. (eds.), Political Parties and the Third Republic (Abuja: CDS Publications), pp.29-36

[25] Nwagwu, B (2010) Constitutional Democracy in Africa, Vol.1, (Spectrum Books Ltd) Ibadan.

[26] O. (eds) Politics and Government: An Introductory and Comparative Perspective. Benin City: Uri Publishing Ltd.

[27] Office of the SSA to the Nigerian Government on MDGs. (2015) Nigeria MDG information System http://nmis.mdgs.gov.ng/

[28] Okoosi-Simbine, A. E, (2010) the Nigerian Legislature: An Appraisal of the Imo Legislature in Democracy and National Development: 1983 and Beyond, Proceedings of the Tenth Annual Conference of the Nigerian Political Science Association University of Nsukka.

[29] Oloka-Onyango J. 2001 (ed), Constitutionalism in Africa Creating Opportunities, Facing Challenges, (Kampala, Fountain Publishers)

[30] Osborn, D., Cutter, A. and Ullah, F. (2015). "Universal Sustainable Development Goals: Understanding the Transformational Challenge for Developed Countries," Report of a study by Stakeholder Forum.

[31] Pelizzo, R. and Stapenhurst, R. (2008).Legislatures and Oversight: A Note" in QuadernidiScienzaPolitica. Publishers, pp. 393 - 411

[32] Sachs, J.D. (2012). "From Millennium Development Goals to Sustainable Development Goals," Lancet, 370: 2,206-211.

[33] Sanga, D. (2011). "The Challenges of Monitoring and deporting on the Millennium Development Goals in Africa by 2015 and Beyond," Journal Statistique Africain, 12: 104-118.

[34] Stair-Hall, A. (2011): Patterns of Democracy: Government Forms and Performance in Thirty-Six Countries, New Haven and London: Yale University Press.

[35] Stapenhurst, R (2012) Determinants of Oversight in a Reactive Legislature: The Case of Brazil, 1988 - 2005. Oxford: University College. UNSTATS (2015) Documunitedents for the forty-sixth session of the Statistical Commission New York, 3 - 6 March 2015 http://unstats.un.org/unsd/statcom/sc2015.htm

[36] www.ng.undp.org/.../nigeria/.../Nigeria\%20transition\%20strategy $\% 20$ to\%20SDGs 